\title{
Study of Humic Acid and Multiantagonis of Streptomyces Sp, Trichoderma Sp Application Techniques for Horticulture Plant on Marginal Soil
}

\author{
Penta Suryaminarsih ${ }^{1}$, Wiwik Sri Harijani, Wanti Mindari, Widi Wurjani \\ Agrotechnology Department \\ Universitas Pembangunan Nasional "Veteran" Jawa Timur \\ Surabaya, Indonesia \\ ${ }^{1}$ penta_s@upnjatim.ac.id
}

\begin{abstract}
Tomato, red pepper and melon are highvalue horticultural crops. Crop production will be decrese couse of pathogenic microorganism and Pest .Some soil saprophytic microorganisms are natural enemies of soilborne pathogenic microorganisms and pests. Streptomyces sp., Trichoderma sp. is a biological agent,decomposer, and a growth hormone producer. The purpose of the experiment to study humic acid and multiantagonis of Streptomyces sp, Trichoderma sp application techniques for horticulture plant on marginal soil. The study was carried out in Pare (regusol soil) and Gresik (vertisol soil), prepared in Completely Randomized Design with different treatment factors for application technic of multiantagonis doses of $100 \mathrm{ml}, 200 \mathrm{ml}$ and $300 \mathrm{ml}$ every plant treatment. Horticulture plants were tomato, chili and melon. The results showed that the Aplication of humic acid and multiantagonic could more increase the production of chilli tomatoes and melons than the production of controls. The average production of tomatoes, melons and peppers in Pare (regusol) is higher than the average production in Gresik (vertisol).
\end{abstract}

Keywords-biological agents, soil fertility, decomposers, hormone, crop production.

\section{INTRODUCTION}

The cultivation of chili, melon and tomato is almost distributed throughout the world, especially in tropical countries. Both red chili and tomatoes plants can thrive in the Indonesian environment which is very suitable for their second habitat. Melon plants is the favored fruit horticultural plants by the people of Indonesia. Gliocladium sp., Streptomyces sp., and Trichoderma sp., are soil saprofit fungi that are used as biological agents, and are active ingredients of bio compost fertilizer [1]. Humid acid was the formula with highgrade organic fertilizer was obtained from a mixture of manure, compost, guano, and straw. High-grade organic fertilizer was not always effective controlling soil salinity and aggregate stability, but also the availability of $\mathrm{N}, \mathrm{N}$ Ammonium inhibits volatilization, decrese soil $\mathrm{EC}$, but soil $\mathrm{pH}$ is increased. Mineralization rate of organic fertilizer on clay-textured soil increased too.

Streptomyces sp., is a biological agent, a microbe that degrades carbon from crop residues and decomposers of recalcitrate protein into proteolysis [2]. Aplication of Streptomyces sp. increased the height plant, amount of fruit, and flower of tomato plants [3]. Trichoderma sp. and Gliocladium sp. is biological agents, functions as biological fertilizers also, which are packaged in compost as $\mathrm{P}$ solvent and $\mathrm{K}$ solvent $[4 ; 5]$, proved that the aplication of Trichoderma sp. and Gliocladium sp. on sunflower seeds, increased plant root growth and plant height. [6], explained that, Streptomyces sp. can oxidize ammonium to nitric acid so that the $\mathrm{pH}$ of the soil becomes 5 , where this $\mathrm{pH}$ is less suitable for the growth of soil-borne pathogens. Streptomyces sp. has a habitat around plant roots (rhizosphere) and a dominant genus in the soil up to 86\%. increase plant growth as Plant Growth Promoting Rhizobacteria (PGPB) [7], Streptomyces as biofertilizer reported by [8] with significant results proven to increase the growth of wheat and soybeans grown on low fertility soils and without fertilization. [9] reported a number of plant growth stimulant compounds produced by Streptomyces and metabolites which function as antifungal and antibacterial for pathogenic organisms.

Trichoderma sp. improves soil conditions and have the ability as biological agents that are influenced pathogenic fungi strains by colonization at the root, controlling pathogenic mycoplora and competitors with various mechanisms such as parasitism, competition and antibiosis [10]. A mixture of biological agents $S$. griseorubens $G$. virens and $T$. harzianum has the ability to inhibit the development of fusarium wilt disease 
severity caused by $F$. oxysporum $f$. sp. lycopersici and increase fruit production [11]. Although there are still many challenges, the utilization of humic acid and multiantagonic streptomyces sp, trichoderma sp. in horticultural plants in marginal soils has arrived at the level of application techniques, with the hope that it can streamline natural resources, conservation and environmental preservation, and produce cheaper and healthier agricultural products .

\section{MATERIALS AND MethodS}

The study was carried out in Pare (regusol soil) and Gresik (vertisol soil), compiled using a Completely Randomized Design with factors doses difference of multiantagononis of Streptomyces sp., Trichoderma application technology treatment $100 \mathrm{ml}, 200 \mathrm{ml}$ and $300 \mathrm{ml}$ every plant. Each treatment repeated three times . Horticulture plants used were tomato, chili and melon plants. Humate applications are carried out once during the planting period while the multiantagonist application was carried out twice. Observation data was fruit production, were analyzed using variance analysis (F test) according to the experimental design used, Completely Randomized Design (CRD). If the treatmentwas significantly different, then further testing was done using $\mathrm{T}$ test .

\section{A. Preparetion tomato, chili, melon seeds}

Preparing the soil by mixing garden soil and compost, 1: 1 stirred until blended, then sterilized by using steam (steamed), then the sterile soil was inserted into the hatchery box and polybag. Healthy seeds of tomato, chili and melon, soaked in $50^{\circ} \mathrm{C}$ warm water, then planted in planting soil in the hatchery box. Then watering every day, after the tomato seeds have perfect leaves (14-21 days) the seeds are ready to be planted on the land.

\section{B. Preparation and application of biological agents.}

Preparing $14^{\text {th }}$ days Strptomyces sp. inoculums and $7^{\text {th }}$ days Trichoderma sp. inoculums in Potato Dextrose Agar on Petridish. Each biological agent 5 colony of 0.5 $\mathrm{cm}$ in diameter was invested in $250 \mathrm{~mL}$ Sugar Potato Extract, then carried out shaking at medium speed for 3 days. Multiantagonist suspensions were prepared with a ratio of $30 \mathrm{~mL}$ Streptomyces $\mathrm{sp} .10 \mathrm{~mL}$ Trichoderma sp, dissolved into $1 \mathrm{~L}$ of water. Application of biological agents in the field was carried out 2 times with the treatment of different doses of $100 \mathrm{~mL}, 200 \mathrm{~mL}$ and 300 $\mathrm{mL}$ of biological agent suspense at 2 weeks and 4 weeks after planting.

\section{Seedling treatment and cultivating}

Tomato, chili and melon seeds were inoculated in Suspension of biological agents on immersion stereofoam consist of 10 holes, then put tomato seeds in holes of sterofoam and placed on top of Petri which had been given a solution of inoculum combination of biological agents that had been prepared. Then the seeds are planted in the land that has been prepared and have been given humic acid. Cultivating the land by prosses and plow it, gived organic fertilizer (manure)and liquid humic acid $5 \mathrm{~mL} / \mathrm{L}$ of water at a certain dose, Aplication the suspension of multiantagonist based on the doses treatment at 2 weeks and 4 weeks after treatment

\section{Observation.}

Crop production is observed by weighing the fruit in the first, second and Third harvests. The character ot ripe fruit was greenish orange or orange red and green yellow for Melon on the 60th day after planting it is weighed per tree according to each dose treatment.

\section{RESULTS AND DISCUSSION}

\section{A. Application of humic acid and multiantagonists in marginal soils}

The result of treatment showed the average production of melon, chilli and tomato plants with multiantagonist and humic acid was higher than the average fruit production without multiantagonists and humic acid (Figure 1).

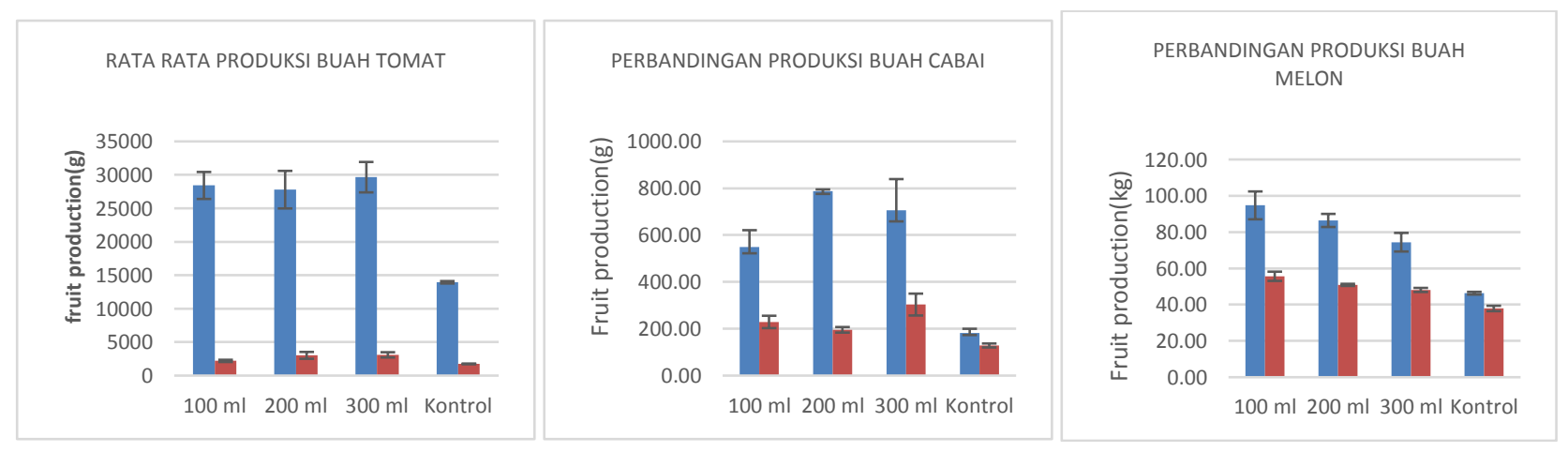

Fig. 1. Avarage fruit production of tomato, Chili and melon with application of multiantagonist of Streptomyces , Trichoderma sp. and humic acids 
Multiantagononis Streptomyces sp. Trichoderma sp. application in horticultural plants can increase plant growth and production because these microorganisms as biological agents can reduce fruit fly pest attacks, uret spodopter and fusarium wilt disease, besides producing PGPR and decomposer microorganisms in the soil. Streptomyces sp., is a carbon degrading microbial from crop residues and decomposer of recalcitrat protein to proteolysis, increasing the height plant, amount of fruit, and flowers of tomato, wheat, soybean, producing secondary metabolites that function as biostimulants and bio-protectants anti-bacterial and fungal $[12 ; 13 ; 14)$. Trichoderma sp. and Gliocladium sp. as biological agents, also function as fertilizer. These biological agents packed in compost as $\mathrm{P}$ solvent and $\mathrm{K}$ solvent, increasing plant root growth and sunflower plant height [15]. Trichoderma sp. can colonize roots, control pathogenic microflora and competitors [16]. Mixture of three biological agents inhiibit the development of fusarium wilt disease severity and improve fruit production produced in the first harvest [17].

\section{B. Horticultural Fruit Production on Regusol (Pare) soil}

The Aplication of humic acid and a mixture of biological agents Strptomyces sp and Trichoderma sp on the land in Pare significantly affected the production of chili, tomato and melon. The results showed that the aplication of biological agents could significantly increase the production of tomato melon and chili fruit compared to plants that were not given biological agents and humic acid. The average production of melon, tomato and chilli fruit that have been treated with Streptomyces sp., Trichoderma sp. showed that the best treatment for melon and chili plants was a dose of 200 $\mathrm{mL} /$ plant and the lowest was for treatment without biological and humic agents. The highest average production of tomato plants is $9885.33 \mathrm{~g}$ with the aplication of a biological agent dose of $300 \mathrm{~mL}$. Whereas the lowest production was $4648.33 \mathrm{~g}$ in tomato plants not given a mixture of biological and humic agents (Table I)

Table I. Avarage Fruit Production of Melon, Chili AND TOMATO AT REgusOl SoIL PARE

\begin{tabular}{|c|c|c|c|}
\hline $\begin{array}{c}\text { Multi } \\
\text { antagonis } \\
\text { dosage }\end{array}$ & $\begin{array}{c}\text { Chili } \\
(\mathrm{gr})\end{array}$ & $\begin{array}{c}\text { Tomatoes } \\
(\mathrm{gr})\end{array}$ & $\begin{array}{c}\text { Melons } \\
(\mathrm{Kg})\end{array}$ \\
\hline $100 \mathrm{~mL}$ & 1182.86 & 9472.33 & 182.86 \\
\hline $200 \mathrm{~mL}$ & 1262.6 & 9263.33 & 262.61 \\
\hline $300 \mathrm{~mL}$ & 1235.04 & 9885.33 & 235.04 \\
\hline Control & $60.53 \mathrm{a}$ & 4648.33 & 15.40 \\
\hline
\end{tabular}

Based on the soil analysis carried out in the preliminary study the type of soil planted with tomatoes, chillies and melons in Pare is Regusol. Regusol soil is low organic content of 1.98 , unable to accommodate minerals and water with good content of potassium (K) 0.26, sodium (Na) 0.82, calcium (Ca) 8.80 and magnesium (Mg) 0.75. Addition of Streptomyces sp. and Trichoderma sp. in regusol soil in Polybag, has a significant relationship to the increasing number of microorganisms in the soil. Addition of humic acid containing organic $\mathrm{C}$ can increase $\mathrm{PH}$, prevent evaporation of $\mathrm{N}$ ammonium (Volatile compounds) and increase soil aggregation so that Streptomyces sp. and Trichoderma sp. in regusol soil can be restrained and developed [18;19].

\section{Horticultural Fruit Production on Vertisol Soil (Gresik)}

The results of the analysis of variance in the average production of tomato and chili fruit by the administration of biological agents Streptomyces sp., Trichoderma sp. And humic acid in vertisol soil showed a non-significant relationship, whereas in melon plants showed significant results. Data on the average production of melon with Streptomyces sp., Trichoderma sp. and humic acid showed that the best treatment for melon plants was $18.54 \mathrm{~kg} / 10$ plants with a dose of $100 \mathrm{~mL} /$ plant and the lowest was the treatment without biological and humic agents, namely 12.20 / 10 plants (figure 1).

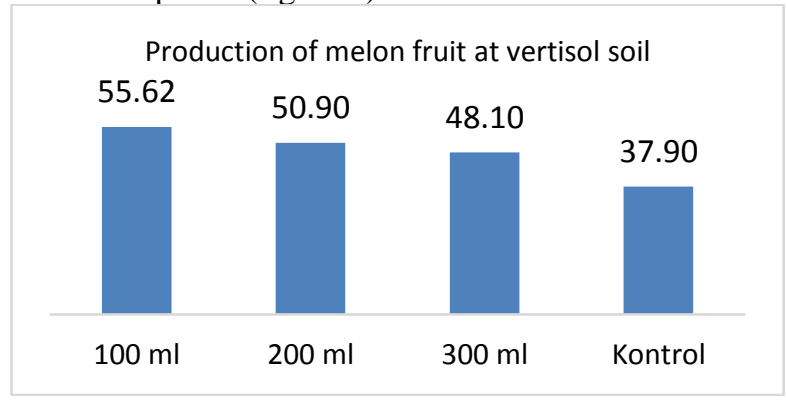

Fig. 2. Bar Chat of average Melon fruit production atvertisol soil Gresik

The vertisol soil type is soil containing $30 \%$ montmorillonite $(\mathrm{Mn})$ clay minerals, easy washed erosion and nutrients, $\mathrm{K}$ and $\mathrm{P}$ are low available for plants, moderate $\mathrm{N}$ is available and low permeability [20;21]. The results of the preliminary study showed the same thing description of the soil are C.organic $0.90, \mathrm{~N}$ total 0.16 , P.Olsen $53.65 \mathrm{mg} / \mathrm{kg}$, total number 52.69 . The content of microorganisms with the addition of Streptomyces sp., Trichoderma sp. showed the development of the number of microorganisms that are not significant, especially the number of Streptomyces 
sp not experiencing development. Soil pH increases, average mineralization of organic fertilizer on texture of clay is slower than sand texture. [22;23]. The slow mineralization of the vertisol soil and the number of microbes that are underdeveloped causes an abundance of microorganisms as decomposers and growth hormone producers have less influence on production.

\section{CONCLUSION}

The average fruits production of melon, chilli and tomato plant with the aplication of multiantagonist Streptomyces sp., Trichoderma sp and humic acid was higher than the average fruit production without the aplication of multiantagonist and humic acid. Dosage Application of multiantagonist Streptomyces sp., Trichoderma sp. and humic acid in horticultural plants of melon and chili in regusol soil is $200 \mathrm{~mL} /$ plant and $300 \mathrm{~mL}$ for tomato plants. Multiantagonist application of Streptomyces sp., Trichoderma sp. and humic acid in horticultural plants in vertisol soil was greater than 300 $\mathrm{mL} /$ plant.

\section{REFERENCES}

[1] S.A. Akladious and S. M. Abba, "Application of Trichoderma harziunum T22 as A Biofertilizer Supporting Maize Growth," Afr. J. Biotechnol., vol. 11, pp. 8672-8683, 2012.

[2] A. Anitha and M. Rabeeth, "Control of Fusarium wilt Tomato by Bioformulation of Streptomyces griseus in Green House Condition.," Afr. J. Basic App. Sci., vol. 1, pp. 9-14, 2010.

[3] A. Basilio, I. Gonzalez, M.F. Vicente, J. Gorrochategui, A. Cabello, A. Gonzalez and O. Genilloud, "Patterns of Antimicrobial Activities from Soil Actinomycetes Isolated under Different Conditions of $\mathrm{pH}$ and Salinity," J. Appl. Microbiol., vol. 95, pp. 814-23, 2003.

[4] S. Compant, G. Brader, S. Muzammil, A. Sessitsch, A. Lebrihi and F. Mathieu, "Use of beneficial bacteria and their secondary metabolites to control grapevine pathogen diseases," BioControl, vol. 58, pp. 435-455, 2013.

[5] T. Doolotkeldieva, S. Bobusheva, and M. Konurbaeva, "Effects of Streptomyces Biofertilizer to Soil Fertility and Rhizosphere's Functional Biodiversity of Agricultural Plants," Adv. Microbiol., vol. 5, pp. 555, 2015.

[6] S. Gruber and V. Seiboth, "Self versus non-self: fungal cell wall degradation In Trichoderma," Microbiol., vol. 158, pp. 26-34. 2012

[7] A.P. Hoerussalam and A.Khaeruni, "Induksi ketahanan tanaman jagung (Zea mays L.) terhadap penyakit bulai melalui seed treatment serta pewarisannya pada generasi S1," Ilmu Pertan. (Agric. Sci.), vol. 16, pp. 42-59, 2013.

[8] A.F. Laila, P. Suryaminarsih, and K.S. Marhaeni J, "Penyalutan Benih Tomat Dengan Agens Hayati Trichoderma Sp. Dan Actinomycetes Sp. Untuk Pencegahan Penyakit Layu Fusarium (Fusarium sp.)," Berk. Ilm. Agroteknologi-PLUMULA, vol. 5, pp. 86-98, January 2016
[9] Q. Li, P. Ning, L. Zheng, J. Huang, G. Li, T. Hsiang, "Effects of Volatile Substances of Streptomycesglobisporus JK-1 on Control of Botrytis cinerea on Tomato Fruit," Biol. Control, vol. 61, pp. 113-120, 2012

[10] W. Mindari, P.E. Sasongko, and Maroeto, "Extent Of Mineralization Organic Fertilizer On Salt Affected Soil And That Implementation On Tomato," ISNAR C2FS Proc. [Nat. Resour. Clim. Change and Food Secur. in Dev. Ctries. Surabaya, Indonesia, pp. 190-200, June 2011]

[11] A. Munawar, M. Wanti, and P. Eddy, "The Dynamics Of Ph, Ec And Redox Of Pond Soil After Application Of Humic Acid,” Int. J. Acad. Res., vol. 5, pp. 187-192, 2017

[12] S.A. Palaniyandi, S.H. Yang, L. Zhang, and J.W. Suh, "Effects of Actinobacteria on Plant Disease Suppression and Growth Promotion," Appl. Microbiol. Biotechnol., vol. 97, pp. 96219636, 2013.

[13] M.A. Rahman, M.Z. Islam, and M.A. Islam, "Antibacterial Activities of Actinomycete Isolates Collected from Soils of Rajshahi, Bangladesh,” Biotechnol. Res. Int., vol. 2011, pp. 857925, 2011

[14] M. Safri, W.S. Harijani, and P. Suryaminarsih, "Uji Daya Hidup Pupa Lalat Buah (Bactrocera Sp.) Menjadi Imago Dengan Pemberian Agensia Hayati Streptomyces sp.,"Berk. Ilm. Agroteknologi-pulmula, vol. 5, pp. 39-49, January 2016

[15] M. Sharma, P. Dangi, and M. Sharma, "Actinomycetes: Source, Identification and Their Application," Int. J. Curr. Microbiol. Appl. Sci., vol. 3, pp. 801-832, 2014.

[16] S. Siddiquee, S.G. Tan and U.K. Yusof, "Isozyme Analisis and Relationships Among Three Species in Malaysia Trichoderma Isolates,” Mycrobiol. Biotechnol., vol. 20, pp. 1266-1275, July 2010.

[17] P. Suryaminarsih, Kusriningrum, Ni'matuzaroh and T. Surtiningsih, "Antagonistic Compatibility of Streptomyces griseurubens, Gliocladium virens and Trichoderma harzianum againts Fusarium oxysporum couse of Tomato Wilt Deseases," Int. J. Plant Soil Sci., vol.5, pp. 82-89, 2015

[18] P. Suryaminarsih, W.S. Harjani, Safri, and Bicha, "Multi Antagonis Streptomyces Sp.(Tomat Pare) Terhadap Lalat Buah Dan Fusarium Sp. Penyebab Layu Tomat In Vitro,” Berk. Ilm. Agroteknologi-pulmula, vol. 5, pp. 21-29, January 2016.

[19] Suharjono, T.H. Kurniati, Soejono, and S. Dewi, "Uji antagonis Trichoderma sp dan Gliocladium sp. Terhadap Fusarium Penybab Penyakit Layu Pada Beberapa Jenis Tanaman Pisang di Kebun Raya Purwodadi Secara in Vitro,” Biota: J. Ilm. Ilmuilmu Hayati, vol. 9, June 2004

[20] S. Steinkellner, R. Mammerder, and H. Vierheilig, "Germination of Fusarium oxysporum in Root Exudates from Tomato plants challenged with diffrent Fusarium oxysporum strains,” Eur. J. Plant Pathol. vol. 122, pp. 395-401, 2008.

[21] S.S.K.P. Vurukonda, D. Giovanardi, and E. Stefani, "Plant Growth Promoting and Biocontrol Activity of Streptomyces spp. as Endophytes," Int. J. Mol. Sci. vol. 19, pp. 952, 2018.

[22] C. Wang, Z. Wang, X. Qiao, Z. Li, F. Li, M. Chen, Y. Wang., Y. Huang, and H. Cui, "Antifungal Activity of Volatile Organic Compounds from Streptomyces alboflavus TD-1," FEMS Microbiol. Lett.,vol. 341, pp. 45-51, 2013.

[23] F. Yaqub and S. Shahzad, "Effect of Seed Pelleting with Trichoderma Sp. and Gliocladium Virens on Growth and Colonization of Roots of Sunflower and Mung Bean by Sclerotium Rolfsii,” Pak. J.Bot., vol. 40, pp. 947-953, 2008. 